\title{
IDENTIFICATION OF LACTIC ACID BACTERIA ASSOCIATED WITH TRADITIONAL CACHAÇA FERMENTATIONS
}

\author{
Fatima C. O. Gomes ${ }^{1}$, Carol L. C. Silva ${ }^{2}$, Cristina R. Vianna ${ }^{2}$, Inayara C. A. Lacerda ${ }^{3}$, Beatriz M. Borelli ${ }^{2}$, Álvaro C. \\ Nunes $^{4}$, Gloria R. Franco ${ }^{5}$, Marina M. Mourão ${ }^{5}$, Carlos A. Rosa ${ }^{2 *}$ \\ ${ }^{1}$ Departamento de Química, Centro Federal de Educação Tecnológica de Minas Gerais, Belo Horizonte, MG, Brasil; \\ ${ }^{2}$ Departamento de Microbiologia, Universidade Federal de Minas Gerais, Belo Horizonte, MG, Brasil; ${ }^{3}$ Universidade José do \\ Rosário Vellano, Divinópolis, MG, Brasil; ${ }^{4}$ Departamento de Biologia Geral, Universidade Federal de Minas Gerais, Belo \\ Horizonte, Brasil; ${ }^{5}$ Departamento de Bioquímica, Universidade Federal de Minas Gerais, Belo Horizonte, Brasil.
}

Submitted: February 19, 2009; Returned to authors for corrections: June 02, 2009; Approved: November 07, 2009.

\begin{abstract}
During the production of traditional cachaça (alembic's cachaça), contamination of the fermented must is one of the factors leading to economic losses in the beverage manufacturing industry. The diversity of bacterial populations and the role of these microorganisms during the cachaça production process are still poorly understood in Brazil. In our work, the fermentation process was followed in two distilleries located in the state of Minas Gerais. The objective of this work was to identify the populations of lactic acid bacteria present during cachaça fermentation using physiological and molecular methods. Lactic acid bacteria were isolated in high frequencies during all of the fermentative processes, and Lactobacillus plantarum and $L$. case $i$ were the most prevalent species. Other lactic acid bacteria were found in minor frequencies, such as $L$. ferintoshensis, L. fermentum, L. jensenii, L. murinus, Lactococcus lactis, Enterococcus sp. and Weissella confusa. These bacteria could contribute to the increase of volatile acidity levels or to the production of compounds that could influence the taste and aroma of the beverage.
\end{abstract}

Key words: Lactic acid bacteria, fermentation, cachaça

\section{INTRODUCTION}

Cachaça is the most traditionally distilled beverage produced in Brazil. It has an alcohol content between 38 and $48 \% \mathrm{v} / \mathrm{v}$ at $20{ }^{\circ} \mathrm{C}(1)$, and the estimated annual production is around 1.3 billion litres. There are around 30,000 traditional cachaça distilleries producing approximately 300 million litres/year in Brazil. The beverage is made by the spontaneous fermentation of fresh sugar cane juice around $16{ }^{\circ}$ Brix. Several studies have shown that sugar cane fermentation for cachaça production is a complex microbial process, involving yeasts and bacteria $(4,5,7,9,11)$. Saccharomyces cerevisiae is prevalent during the fermentative process but several other yeast species can exist in minor frequencies $(4,7,9)$. 
Lactic acid bacteria are regarded as contaminants of cachaça fermentation. They can also deteriorate harvested sugar cane, thereby reducing the sugar content (3). These bacteria compete with yeasts for the sucrose in the sugar cane juice, which reduces the ethanol yield of fermentation. Schwan et al. (11) showed that bacterial growth was almost entirely suppressed during the production of cachaça in a traditional distillery in Minas Gerais, and that the ratio of yeasts to bacteria was never less than 80:1, even reaching 1052:1 after 4 $\mathrm{h}$ of fermentation. These authors have also showed that lactic acid bacteria were the most common bacterial group, although they did not propagate during fermentation. Lactic acid bacteria also produce secondary metabolites, including lactic and acetic acids, which can be responsible for the elevated levels of volatile acidity in cachaça (10). Carvalho Netto (2) found as prevalent lactic acid bacteria the species Lactobacillus hilgardii, L. plantarum, L. brevis, L. casei, Leuconostoc mesenteroides and Lc. citreum in four samples collected during the cachaça fermentation in an artisanal distillery in São Paulo. The correct identification of the populations of lactic acid bacteria associated with cachaça fermentation can give information on their metabolism and the influence of the secondary compounds produced by these microorganisms for the flavour of the beverage. In our study, we examined the bacterial populations present during cachaça fermentation in two traditional distilleries, using physiological and molecular methods.

\section{MATERIALS AND METHODS}

Samples were collected in two traditional distilleries in the cities of Esmeraldas and Carandai, both of which are located in the state of Minas Gerais. In the Esmeraldas distillery (Distillery 1), the samples were collected in June and July 2002, and in July and August 2004, whereas in the Carandai distillery (Distillery 2) the samples were collected in May and June 2005, and in August and September 2005. Fermentation was done using selected starter $S$. cerevisiae strains in two experiments in both distilleries as described in Gomes et al.
(4). The starter $S$. cerevisiae strains were grown on modified Sabouraud agar (glucose $2 \%$, peptone $1 \%$, yeast extract $0.5 \%$ and agar $2 \%$ ) at room temperature for $24 \mathrm{~h}$, from which $1 \mathrm{ml}$ of a suspension containing about $1 \cdot 10^{7}$ cells was used to inoculate flasks containing $100 \mathrm{ml}$ of SCY broth (sugarcane juice $50 \%$, glucose $0.5 \%$, yeast extract $0.5 \%$ and distilled water $50 \%$ ). The flasks were incubated in an incubator shaker (New Brunswick Scientific) at $150 \mathrm{rev} \min$ at $25 \pm 1^{\circ} \mathrm{C}$ for $24 \mathrm{~h}$. After this period, the pre-inoculum was transferred to flasks with 51 of SCY broth, and incubated at room temperature (25 $\pm 3^{\circ} \mathrm{C}$ ) for $24 \mathrm{~h}$. Ten litres of this second pre-inoculum was added to the vats. The fermentations were conducted in steel vats of 15001 of capacity. The pre-inoculum was mixed with 901 of sugarcane juice at $8^{\circ}$ Brix. After 24 h, a volume of 2001 of sugarcane juice at $10^{\circ} \mathrm{Brix}$ was added to the fermentation vat. On the third day, 3001 sugarcane juice at $12{ }^{\circ}$ Brix were added. On the fourth day, 4001 sugarcane juice at $20^{\circ}$.

Brix were added to the vat containing the selected yeast strain, to a final volume of 1000 1. After $24 \mathrm{~h}$, the wine produced was distilled, and a new fermentative cycle began, using the same starter. Sampling was started 7 days after the beginning of the experiment; this date also coincided with the conduction of the second distillation process. The time observed before the actual sampling is important, because volatile acidity is excessively high during the early stages of the first distillation (around $200 \mathrm{mg}$ acetic/100 $\mathrm{ml}$ anhydrous alcohol), and normally producers do not use the cachaça from the first distillation. The duration of the experiments was determined by observing the cachaça volatile acidity levels and fermentation times daily (4). Vat contents that had acetic acid levels over $150 \mathrm{mg} 100 / \mathrm{ml}$ of anhydrous alcohol or fermentation cycles lasting over $30 \mathrm{~h}$ were discarded. Samples of the fermented must were collected from the distillery in Esmeraldas on days 7, 14, 21, 28 and 35 after the beginning of the fermentative process during the first experiment, and on days 7, 14 and 25 during the second experiment; in the distillery in Carandai the samples of the fermented must were collected on days 7, 14, 21, 28 and 35 during the first and second experiments. 
The samples were collected using sterile $500 \mathrm{ml}$ flasks, transported to the laboratory in an ice bath and processed within $5 \mathrm{~h}$. Serial 10-fold dilutions of the samples were inoculated $(0.1 \mathrm{ml})$ in triplicate on Man Rogosa Sharp (Difco, USA) agar supplemented with $100 \mathrm{mg} \mathrm{l}^{-1}$ cycloheximide (Sigma, USA). The plates were incubated in an anaerobic chamber (Forma Scientific Company, Marietta, OH, USA) containing an atmosphere of $85 \% \mathrm{~N}_{2}, 10 \% \mathrm{H}_{2}$ and $5 \% \mathrm{CO}_{2}$, at $37{ }^{\circ} \mathrm{C}$ for $48 \mathrm{~h}$. Plates containing between 30 and 300 bacterial colonies of the samples of each sampling collection were examined, and each different morphotype was counted, purified and maintained in liquid nitrogen storage for later identification. These morphotypes represented the number of each species of lactic acid bacteria in each vat in the different times after the identification process.

For the physiological identification of each different morphotype of lactic acid bacteria, the miniaturized plate technique was utilized (12) as described in Lacerda et al. (6). Assimilation of the following sugars was tested: D-ribose, Darabinose, D-xylose, D-galactose, L-sorbose, D-maltose, Dglucosamine, D-lactose, D-sucrose, L-rhamnose, D-trehalose, D-cellobiose, D-melibiose, D-melizitose, glycerol, D-raffinose, myo-inositol, D-ribitol, D-mannitol, D-glucitol, salicin and Dgluconate. Bacteria were grouped according to their sugar utilization profiles. Representative isolates from each bacterial group were confirmed by PCR amplification of the intergenic segment between the $16 \mathrm{~S}$ and $23 \mathrm{~S}$ rDNA subunits (14) followed by restriction enzyme digestions specific for Lactobacillus (8).

The intergenic spacer region from $16 \mathrm{~S}$ to $23 \mathrm{~S}$ of each isolate was amplified using the primers 16-1A (5'GAATCGCTAGTAATCG-3', corresponding to the sequence between nucleotides 1361 and 1380 of the 16S rRNA gene of Lactobacillus casei), and 23-1B (5'GGGTTCCCCCATTCGGA-3', corresponding to nucleotides 123 to 113 of the 23S rRNA gene of L. casei). PCR conditions followed the protocols described in Lacerda et al. (6). The enzymes used in this study were NcoI, EcoRI, HindIII, EcoRV, SphI, DraI, SspI, VspI, HincII, SfuI and NheI. The enzymes SphI, NcoI and NheI cleave inside the $16 \mathrm{~S}$ gene; SspI, SfuI, DraI, VspI, HincII and EcoRI cleave inside the spacer region of the $L$. casei group and in the $23 \mathrm{~S}$ gene of the $L$. acidophilus group (8). All restriction enzymes were used according to the manufacturer's instructions (Promega Corporation, Madison, WI, USA). The species identifications were confirmed by sequencing of the 16-23S intergenic region using an Alf Express 2.0 Automatic DNA sequencer (GE Healthcare Life Sciences, USA) and the primers 16-1A and 231B. Existing sequences for other lactic acid bacteria were retrieved from GenBank.

\section{RESULTS AND DISCUSSION}

Tables 1 and 2 show the frequencies of lactic acid bacteria isolated from the vats during fermentation in both cachaça production experiments. One hundred and sixty-nine isolates of lactic acid bacteria were identified using physiological and molecular methods. The counts of lactic acid bacteria were high during the fermentation process, and L. casei and $L$. plantarum were the most abundant species. L. perolens was isolated from most of the fermentation vats in distillery 1 , whereas in distillery 2, it was only isolated from two vats at 14 days of fermentation. Other lactic acid bacteria were found in minor frequencies, such as L. ferintoshensis, L. fermentum, L. jensenii, L. murinus, Lactococcus lactis, Enterococcus sp. and Weissella confusa. Lactobacillus ferintoshensis and L. jensenii were isolated from the vats in the first experiment in both distilleries. Lactococcus lactis, W. confusa and Enterococcus sp. were only isolated from the vats of distillery 2. CarvalhoNetto et al. (2) characterized the bacterial community in the production of cachaça by partial sequencing of the $16 \mathrm{~S}$ rDNA gene using a cultivation-independent technique. Five hundred and eighty-seven sequences were analyzed revealing the presence of 170 operational taxonomic units. The genus Lactobacillus was predominant, accounting for approximately $66 \%$ of the sequences, and L. hilgardii and L. plantarum were the most frequently found species. Other species were found in minor frequencies, such as Curtobacterium flaccumfaciens, $L$. 
casei, Leuconostoc mesenteroides and L. citreum. Thirty-two percent of the sequences could not be identified at the species level. However, Carvalho-Netto et al. (2) collected only four samples from a fermentation vat in a distillery located in the state of São Paulo. In our work, using a cultivation-dependent technique, the genus Lactobacillus was also predominant in the fermentation vats, with the species L. plantarum and L. case $i$ as the most prevalent species in the vats. These differences could be related to the different approaches used, and to regional differences in the composition of the lactic acid bacteria community, since Carvalho-Netto et al. (2) worked with fermentation vats in São Paulo state, and our work was done in distilleries from Minas Gerais state.

Table 1. Population counts of lactic acid bacteria from the vats of the traditional cachaça distillery 1.

\begin{tabular}{|c|c|c|c|c|c|c|}
\hline & \multirow[t]{2}{*}{ Species } & \multicolumn{5}{|c|}{ Times $^{1}$} \\
\hline & & $\mathbf{I}$ & II & III & IV & $\mathbf{V}$ \\
\hline \multicolumn{7}{|c|}{ Vat I } \\
\hline \multirow[t]{6}{*}{$A^{2}$} & Lactobacillus jensenii & & & $1.0 \times 10^{5}$ & & \\
\hline & L. ferintoshensis & & $3.3 \times 10^{7}$ & & & \\
\hline & L. fermentum & & & & & $2.0 \times 10^{6}$ \\
\hline & L. perolens & & & & & $1.7 \times 10^{7}$ \\
\hline & L. plantarum & $3.8 \times 10^{5}$ & $6.4 \times 10^{8}$ & $3.6 \times 10^{6}$ & $8.0 \times 10^{8}$ & $>3.0 \times 10^{8}$ \\
\hline & L. casei & $3.5 \times 10^{4}$ & $3.6 \times 10^{8}$ & $5.4 \times 10^{6}$ & $6.2 \times 10^{6}$ & \\
\hline \multirow[t]{2}{*}{$\mathbf{B}^{3}$} & L. casei & $1.8 \times 10^{8}$ & $9.5 \times 10^{8}$ & $8.6 \times 10^{7}$ & & \\
\hline & L. perolens & $1.3 \times 10^{7}$ & $2.1 \times 10^{8}$ & & & \\
\hline
\end{tabular}

Vat II
A L. perolens
L. plantarum
B L. casei
L. perolens
L. plantarum

$2.9 \times 10^{5}$

$2.3 \times 10^{7}$

$1.2 \times 10^{9}$

$1.0 \times 10^{7}$

$1.0 \times 10^{7}$

Vat III
A L. casei
L. ferintoshensis
L. perolens
L. plantarum

B L. casei

L. perolens

L. plantarum

\section{$1.1 \times 10^{9}$}

$1.5 \times 10^{9}$

Vat IV

\section{A L. casei \\ L. ferintoshensis \\ L. plantarum}

B L. casei

L. perolens
$6.7 \times 10^{8}$ $1.5 \times 10^{6}$

$8.3 \times 10^{5}$

$1.0 \times 10^{7}$ $1.3 \times 10^{5}$

$5.5 \times 10^{5}$

$1.2 \times 10^{8}$

$4.3 \times 10^{6}$

$3.8 \times 10^{8}$

$9.9 \times 10^{8}$

$1.4 \times 10^{8}$

$2.6 \times 10^{7}$

$2.0 \times 10^{7}$

${ }^{1}$ Times I, II, III, IV and V were 7, 14, 21, 28 and 35 days after the start of fermentation respectively, for the first experiment, , and were 7, 14 and 25 days after the start of fermentation, respectively, for the second experiment.

${ }^{2}$ A - first experiment (June and July of 2002)

${ }^{3}$ B - second experiment (July and August of 2004). 
Table 2. Population counts of lactic acid bacteria from the vats of the traditional cachaça distillery 2.

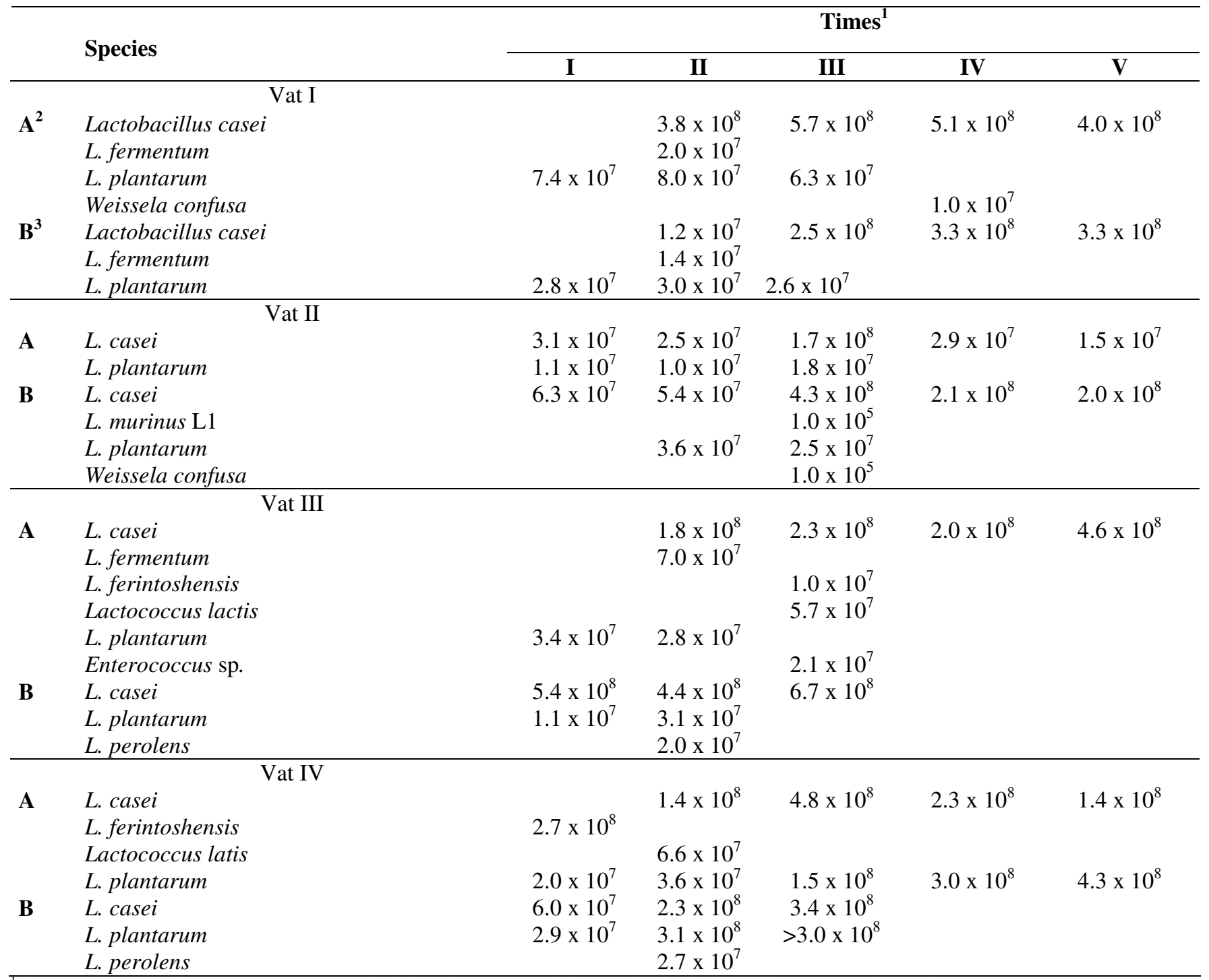

${ }^{1}$ Times I, II, III, IV and V were 7, 14, 21, 28 and 35 days after the start of fermentation for both the first and second experiments.

${ }^{2} \mathrm{~A}$ - first experiment (May and June of 2005)

${ }^{3} \mathrm{~B}-$ second experiment (August and September of 2005).

The digestion profiles of the 16S-23S rDNA spacer region were sufficient to distinguish most lactobacilli at the species level (Table 3). Four isolates of lactic acid bacteria could not be identified using only enzyme restriction analysis. Three of the isolated bacteria were identified as $L$. plantarum by sequencing the 16-23S intergenic region. One isolate was identified as Enterococcus sp. since it presented only $93 \%$ sequence similarity with Enterococcus hirae (GenBank accession number AY50918).

The number of species of lactic acidic bacteria was high in vat I of distillery 1 and vat III of distillery 2 during the first experiment. In spite of the high counts of lactic acid bacteria, no correlation was observed between high bacteria counts and wine acidity (data not showed). One of the factors responsible for economic loss during cachaça production is the excessive acidity of the wine. This problem is directly linked to bacterial populations. Lactic acid bacteria can represent $71 \%$ of the Gram-positive isolates during cachaça production (11). Lactic acid bacteria are considered contaminants of cachaça fermentation, and they can deteriorate harvested sugar cane, thereby reducing the sugar content, which reduces the ethanol yield during fermentation (3). However, it is unclear whether 
bacterial contamination affected ethanol productivity (13). The production of lactic and acetic acids by lactic acid bacteria can be responsible for the elevated levels of volatile acidity in cachaça (10). A precise correlation between the presence of lactic acid bacteria in cachaça fermentation and the secondary compounds responsible by the flavour of the beverage has not yet been shown. Bacterial contaminants create a constant drain on the carbon available for conversion to ethanol and compete for growth factors needed by yeast (13). However, our results showing the presence of high counts of lactic acid bacteria present in fermentation vats indicates that further attempts should be made to study these populations and determine if they play an important role in the fermentation process.

Table 3. Differentiation of lactic acid bacteria by restriction analysis of the $16 \mathrm{~S}-23 \mathrm{~S}$ region of rDNA.

\section{Enzymes}

\begin{tabular}{|c|c|c|c|c|c|c|c|c|c|c|c|c|}
\hline Species & $\begin{array}{l}\text { Number of } \\
\text { isolates }\end{array}$ & DraI & EcoRI & $E c o R V$ & Hincll & HindIII & NcoI & NheI & SfuI & SphI & SspI & VspI \\
\hline Lactobacillus casei & 69 & $+^{\mathrm{a}}$ & $-{ }^{a}$ & + & - & + & - & - & - & - & - & + \\
\hline L. ferintoshensis & 9 & - & - & - & + & + & - & - & - & + & + & + \\
\hline L. fermentum & 8 & - & - & - & - & - & - & $++^{b}$ & - & + & - & + \\
\hline L. jensenii & 1 & - & - & + & - & - & - & - & - & - & - & - \\
\hline L. murinus & 1 & + & - & - & $+{ }^{\mathrm{b}}$ & + & - & - & - & - & - & - \\
\hline L. perolens & 17 & - & - & + & $+{ }^{b}$ & + & - & - & - & - & - & - \\
\hline L. plantarum & 57 & - & - & - & + & - & - & - & $+{ }^{b}$ & + & + & + \\
\hline Lactococcus lactis & 5 & + & - & - & - & - & - & - & - & - & - & - \\
\hline Weissela confusa & 2 & + & - & - & - & + & - & - & - & - & + & - \\
\hline
\end{tabular}

${ }^{a}$ Plus (+) and minus (-) signs indicate cleavage or lack of cleavage of the PCR amplicon, respectively.

${ }^{\mathrm{b}}$ Plus $(+)$ is only for the first intergenic spacer region.

\section{ACKNOWLEDGMENTS}

This work was supported by the Conselho Nacional de Desenvolvimento Científico e Tecnológico (CNPq) and Fundação de Amparo à Pesquisa do Estado de Minas Gerais (FAPEMIG).

\section{REFERENCES}

1. Brasil (2005). Ministério da Agricultura. Instrução normativa $\mathrm{n}^{\circ} 13$ de 29 de junho de 2005. Diário Oficial da União, Brasília, 29 de junho de 2005. Available at: http:// www.agricultura.org.br, accessed on 24 November.

2. Carvalho-Netto, O.V.; Rosa, D.D.; Camargo, L.E.A. (2008) Identification of contaminat bacteria in cachaça yeast by 16S RDNA gene sequencing. Sci. Agric., 65:508-515.

3. Gallo, C.R. (1992). Identificação de bactérias contaminantes da fermentação alcoólica. STAB., 2: 30-34.

4. Gomes, F.C.O.; Silva, C.L.C.; Marini, M.M.; Oliveira, E.S.; Rosa, C.A. (2007). Use of selected indigenous Saccharomyces cerevisiae strains for the production of the traditional cachaça in Brazil. J. Appl. Microbiol.,
103: $2438-2447$.

5. Guerra, J.B.; Araújo, R.A.C.; Pataro, C.; Franco, G.R.; Moreira, E.S.A.; Mendonça-Hagler, L.C.; Rosa, C.A. (2001). Genetic diversity of Saccharomyces cerevisiae strains during the $24 \mathrm{~h}$ fermentative cycle for production of the artisanal Brazilian cachaça. Lett. Appl. Microbiol., 33: 106-111.

6. Lacerda, I.C.A.; Miranda, R.L.; Borelli, B.M.; Lachance, M.A.; Nunes, A.C.; Nardi, R.M.; Rosa, C.A. (2005). Lactic acid bacteria and yeasts associated with spontaneous fermentations during the production of sour cassava starch in Brazil. Int. J. Food Microbiol., 105: 213-219.

7. Morais, P.B.; Rosa, C.A.; Linardi, V.R.; Pataro, C.; Maia, A.B.R.A. (1997). Characterization end succession of yeast populations associated with spontaneous fermentation for Brazilian sugar-cane 'aguardente' production. World J. Microbiol. Biotech., 13: 241-243.

8. Moreira, J.L.S.; Mota, R.M.; Horta, M.F.; Teixeira, S.M.R.; Neumann, E.; Nicoli, J.R.; Nunes, A.C. (2005). Identification to the species level of Lactobacillus isolated in probiotic prospecting studies of human, animal or food origin by $16 \mathrm{~S}-23 \mathrm{~S}$ rRNA restriction profiling. BMC Microbiol., 5: 15 .

9. Pataro, C.; Guerra, J.B.; Petrillo-Peixoto, M.L.; Mendonça-Hagler, L.C.; Linardi, V.R.; Rosa, C.A. (2000). Yeasts communities and genetic 
polymorphism of Saccharomyces cerevisiae strains associated with artisanal fermentations in Brazil. J. Appl. Microbiol. 88: 24-31.

10. Rosa, C.A.; Soares, A.M.; Faria, J.B. (2009). Cachaça production. In: Ingledew, W. M. (eds). The Alcohol Textbook. 5th Edition. Nottingham: Nottingham University Press, p. 481-490.

11. Schwan, R.F.; Mendonça, A.T.; Silva, J.J.J.; Rodrigues, V.; Wheals, A.E. (2001). Microbiology and physiology of cachaça (Aguardente) fermentations. Antonie van Leeuwenhoek 79:89-96.

12. Sharpe, M.E. (1979). Identification of the lactic acid bacteria. In:
Skinner, F.A.; Lovelock, D.W. (eds). Identification Methods for Microbiologists. Academic Press, London, 1979, p. 233-259.

13. Skinner, K.A.; Leathers, T.D. (2004). Bacterial contaminants of fuel ethanol production. J. Ind. Microbiol. Biotechnol. 31: 401-408.

14. Tannock, G.W.; Tilsala-Timisjarvi, A.; Rodtong, S.; Ng, J.; Munro, K.; Alatossava, T. (1999). Identification of Lactobacillus isolates from the gastrointestinal tract, silage, and yoghurt by 16S-23S rRNA gene intergenic spacer region sequence comparisons. Applied Environ. Microbiol. 65: 4264-4267. 